\title{
Three Colombian Peace Processes: A Brief Analysis from the Perspective of Three PACS Theories
}

\author{
Tres procesos de paz en Colombia: un breve análisis desde tres perspectivas de los estudios de paz y conflicto* \\ Leonardo Rafael Luna Eslava ${ }^{\text {a }}$ \\ Corporación Universitaria Iberoamericana, Colombia \\ lunal@myumanitoba.ca \\ ORCID: https://orcid.org/0000-0002-4641-6496 \\ DOI: https://doi.org/10.11144/Javeriana.papo25.tcpp \\ Abstract: \\ Received: February 22, 2020 \\ Accepted: June 22, 2020 \\ Published: December 30, 2020
}

Peace agreements are complex endeavours that can be carried out from different angles. The perspectives used depend not only on the conflict dynamics but also on the political ideology of each government and that of the international forces that have their own interests concerning the pursuit of peacebuilding in conflict zones. The framework used in each peace agreement has an impact on the different stages of the process, including exploration, negotiation, the final agreement and its implementation. This paper analyses three peace processes implemented by the Colombian Government and armed groups from 1982 to 2016. I use three Peace and Conflict Studies (PACS) theories to analyze the structure used in each peace process that include realism, democraticliberal peace, and conflict resolution theories. I conclude that only the most recent peace agreement, which ended in 2016 between FARC-EP and the Colombian Government incorporated significant elements from the conflict resolution framework, the other two processes fluctuate between realism and the democratic-liberal peace.

Keywords: Colombian conflict, Colombian peace agreement, realism, democratic-liberal peace, conflict resolution.

\section{Resumen:}

Los acuerdos de paz son esfuerzos complejos que pueden llevarse a cabo desde diferentes ángulos. Las perspectivas utilizadas para afrontarlos dependen no solo de la dinámica del conflicto, sino también de la ideología política de cada gobierno y de las fuerzas internacionales que tienen sus propios intereses con respecto a la búsqueda de la consolidación de la paz en las zonas de conflicto. El marco utilizado en cada acuerdo de paz tiene un impacto en las diferentes etapas del proceso, incluida la exploración, la negociación, el acuerdo final y su implementación. Este documento analiza tres procesos de paz implementados por el gobierno colombiano y los grupos armados desde 1982 a 2016. Se utilizan tres teorías de Estudios de Paz y Conflictos (PACS) para analizar la estructura utilizada en cada proceso de paz que incluye el realismo, la liberal-democrática y las teorías de resolución de conflicto. Se concluye que solo el acuerdo de paz más reciente que finalizó en 2016 entre las FARC-EP y el gobierno colombiano incorporó elementos significativos del marco de resolución de conflictos, los otros dos procesos fluctúan entre las teorías del realismo y la liberal-democrática.

Palabras clave: Conflicto colombiano, acuerdo de paz colombiano, realismo, paz democrático-liberal, resolución de conflictos.

\section{Introduction}

Colombia is a country with a long history of peace negotiations. The peace negotiation endeavours started at the beginning of the 19th century, with negotiations between Antonio Nariño and Camilo Torres, to the present day with negotiations between the national government and the Revolutionary Armed ForcesPeople's Army (FARC-EP). This long history of peace negotiations should contain enough empirical material to have a solid research agenda of studies on negotiated peace; however, it just recently emerged as an area of study in the Colombian academe (Valencia Agudelo, 2017). It is disconcerting that academic research for peace, in particular, that aimed at analyzing negotiated peace, does not exceed two decades. The first academic papers appear only in the mid-1990s. Previously, interest was focused almost exclusively on the issues of violence and the internal armed conflict (Valencia, 2016).

Author notes

a Autor de correspondencia. Correo electrónico: lunal@myumanitoba.ca 
Therefore, it seems there is a lack of examination into the Colombian peace agreement that blurs an objective analysis of the different peace processes in order to unveil their strengths and weaknesses, as well as nuances and complexities. In this paper, I aim to analyse three peace agreements that were carried out by Colombian governments and armed groups from 1982 to 2016. I chose this period of time because scholars agree that during the 1982 peace agreement there was a turning point whereby the parties decided to resolve the conflict via negotiation instead of military actions (Gutiérrez Loaiza, 2012). I use three PACS theories to analyse the framework used in each peace process that include realism, democratic-liberal peace, and conflict resolution theories. I conclude that only the most recent peace agreement that ended in 2016 between FARC-EP and the Colombian government incorporated significant elements from the conflict resolution framework, the other two processes fluctuate between realism and the democratic-liberal peace.

\section{Analytical Frameworks for Peace Processes}

International relations is an area of political science that provides analytical framework to help understanding peace negotiation or conflict resolution. This area focuses mainly on what Charles Hauss (2010) calls traditional perspectives. Those traditional perspectives are framed as realism and democratic liberalism.

\section{Realism}

Realists reach more pessimistic assumptions about the probability of win-win conflict resolution. People affiliated with this approach focus on power politics because the most important challenge faced by states is the protection of national security (Hauss, 2010, p. 29). The use of power is an attempt to get another state or party in conflict to act contrary to its own wishes and interests, which means that the state would be required to use its power by at least threatening the use of force. Realists expect states to behave rationally by calculating the possible occurrence of benefits and drawbacks in foreign policy decision-making. One of the main goals of realists is to ensure that one of the parties involved in a conflict wins or at least avoids losing, instead of seeking any negotiation (Hauss, 2010, p. 30). From this perspective, win-win endings are possible only when both sides have reached the mutually hurting stalemate (Hauss, 2010, p. 31).

In the Colombian case, it is possible to mention that before the 1982-1986 administration of Belisario Betancur, realism was the predominant perspective that framed the idea of pursuing the peace in Colombia. One example that supports this statement is that the president preceding Betancur's administration, Julio César Turbay, took over the government a year after a popular strike in 1977 and had to cope with the assassination of Rafael Pardo Buelvas in 1978, who was the former Minister of Agriculture and former Minister of Government during the 1977 strike. Several days after the assassination of the former Minister, President Julio César Turbay approved the state of siege, as enacted in the 1923 decree or the Security Statute. This allowed the military criminal justice board to judge a series of crimes committed by civilians against other civilians and the military through Oral Councils (Wills Obregón, 2015, p. 27).

There are some significant critics to this traditional approach. First, people who are involved in the conflict believe very strongly in the justice of their cause. What is crucial is that those beliefs guide people's behaviour more than the "rationality" idea proposed by realism. In addition, there are other psychological factors that are not usually addressed in this perspective, and in some ways, help to perpetuate conflict such as the image of the enemy, the stereotypical thinking of certain political leaders that biases their actions, and the country's culture that often veils unspoken values that protect conflicts (Hauss, 2010). In Colombia, these issues were only addressed recently. Previously, the strategy had mainly been to impose state power and a political and economic vision over a pluralistic population with differentiated needs and perspectives, but also the existing political bipartisanship that determined the exclusion and stigmatization of the political opponent. 


\section{Democratic and Liberal Peace}

The democratic and liberal peace model usually includes disarmament, security reform, a market economy, demobilization and reintegration (DDR), civil society enhancement, and democratization programmes (Mac Ginty, 2006, p. 34). This framework includes the following assumptions: 1) unlike realism, liberal and democratic peace shares the view that humans are capable of rational calculation. There is a belief that liberal democracies are reasonable, predictable and trustworthy because they are governed by their citizen's true interest. 2) There is an association between political organization within the state and the external behaviour of the state. In other words, the logic of the democratic peace proposition is interventionist because states are open to the strong influence of external actors. 3) The strengthening of democracy will bring about peace (Mac Ginty, 2006, p. 43).

In general, this form of liberalism and democracy has been promoted by leading states, international organizations, and international financial institutions; more precisely, the idea of free markets is endorsed by these institutions. In this perspective, there is a double application of free market and electoral democratization (Mac Ginty, 2006, p. 45). Liberalism has provided the intellectual rationale for the elevation of the individual to the position of a citizen with prior rights over the sovereign or the state. Central to liberal claims is the negotiated restraint of the state in its interference in the realm of the individual. Liberalism still stresses individual rights and emancipation; however, it also stresses the importance of the free market that often contradicts social justice (Mac Ginty, 2006, p. 46).

On the other hand, because of its international implication, democratic and liberal peace provides an opportunity for humanitarian interventions to deliver aid to civilians and refugees. The application of international aid is seen as part of the overall peace processes. In the Colombian conflict, humanitarian intervention has been more salient over the last decades. In addition, this perspective embraces the political diplomacy of "sticks and carrots" where the state and its allies use the threat of force to induce their adversary to go along with their wishes while simultaneously carrying out negotiations (Hauss, 2010).

Some critics point out that there is no empirical basis for the argument that economic performance is necessarily tied to constitutional democracy and Human Rights advocates have done little to reduce the enthusiasm of the supporters of market-led liberalism and democratization. Also, the contribution to peace made by free markets has been mixed. The correlation between free trade and the absence of inter-state war is unquestionable. Despite the resourcefulness of the market and its ability to emancipate some individuals and groups, the private profit, in many circumstances, comes at the expense of public goods. Profit and peace are very different things (Mac Ginty, 2006, p. 48).

Democracy does not always contribute to positive peace or social justice. Election-specific pitfalls for the post-civil war society and the international community abound: the failure to provide adequate security for campaigning; the absence of an accurate electoral roll and organisational capacity to stage an election; the danger that the electoral process may become an arena for the continuation of ethno-national conflict, and a premature election that precedes the establishment of mass participation political parties. In many cases, rather than challenge authoritarianism, elections can consolidate it via the ballot box (Mac Ginty, 2006, p. 50). Finally, the most fundamental criticism to this democratic peace thesis is its irrelevance to the pressing reality of the prevalence of ethnonational tension and war. It seems that this thesis only applies to inter-state war (Mac Ginty, 2006, p. 44).

\section{Conflict Resolution Theory}

Conflict Resolution (CR) and Conflict Transformation (CT) are emerging perspectives often used by conflict scholars and peacebuilding practitioners as undistinguishable terms. However, there are slight 
differences that are important to point out before any further analysis. CR is "an umbrella term" for the variety of methods and approaches to deal with conflicts (Wani et al., 2013, p. 43). In order to overcome conflict roots, CR implementation includes activities to change structural and behavioural aspects in the short and medium term. The process focuses more on the relationships between the parties rather than the content of the specific outcome. On the other hand, CT is an "open-ended, long-term, multi-track, and dynamic process, which significantly widens the scope of actors involved" (Wani et al., 2013, p. 40). Some scholars think that the concept of transformation brings some complexities, specially because it seems to "lack precision and clarity" (Ryan, 2009, p. 310). The definition of transformation has a range of nuances depending on the case and context.

In this case, I prefer to use CR theory as a broader perspective to analyse peace agreements. The reason is that CR aims "to eliminate the violent and destructive manifestations of conflict that can be traced back to the unmet needs and fears of the parties in conflict" (Wani et al., 2013, p. 36). This perspective focuses on the agreements that solve discordances between the parties, accept each other as interlocutors, and "cease all violent action against each other" (Wallensteen, 2002, p. 8 as cited in Wani et al., 2013, p. 38). In addition, CR includes some elements that are also implicit in CT such as the importance of working at the grassroots level and building local capacities (Pearson \& Lounsbery, 2009). Also, CR can use the concept of "positive peace" from neighboring fields such as peace studies. Positive peace is understood as a peace development that focus on the structural, social, cultural, economic, political, and individual dimensions that are fostering and maintaining such deep social divisions, exclusion, and Human Rights violations (Galtung, 1975). "The positive peace tradition started with the realization that the causes of war were related to oppressive economic and social conditions" (Jeong, 2000 as citied in Beriker, 2009).

CR as specialised field became more common between 1990 and 2000 (Wani et al., 2013; Beriker, 2009). This theory provides concrete tools for daily formulation and execution of liberal foreign policy (Beriker, 2009). CR theory focuses on a win-win outcome. From this perspective, it is understood that it is possible to envision a win-win result that would satisfy all parties in a conflict. To achieve a win-win outcome it is necessary that the parties involved in a conflict understand that peacebuilding processes are a long-term interest, and that it is important to look for new and creative solutions to conflict. The focus should be on general goals rather than specific demands. Parties should treat each other with respect and dignity, and they must understand that a complex conflict cannot be settled with a single agreement (Hauss, 2010).

One of the premises of this approach is that a successful CR process requires meeting people's needs at least in the medium to long term (Hauss, 2010). This premise implies the need to think about how everyone's actions affect others as a system. Effective win-win CR occurs when the parties reach an agreement that satisfies them all. "In the best of circumstances, they are able to resolve the conflict once and for all by eliminating the issues that gave rise to in the first place" (Hauss, 2010, p. 43). However, this perspective does not occur magically. It requires hard work, creativity, and flexibility from everybody involved. The solution usually involves stepping back from the specific demands each side has, to consider broader concerns they both share (Hauss, 2010, p. 44). Some of the difficulties of this CR approach are that it needs political will to put it into practice, so that the leadership addresses the fundamental injustices and inequalities that gave rise to the conflict in the first place. In addition, the win-win outcomes only occur if the parties can break down their image of the enemy, and deal with other psychological factors that demonize each other.

In this perspective, the role of a "neutral" third party is critical, especially in the pre-negotiation stage (Hauss, 2010, p. 46). Third parties can ease the tensions among parties instilling trust. In addition, win-win decisions have to include components such as truth acknowledging the wrongs that have been committed; mercy as the forgiveness of those wrongs and a new beginning to the relationship; justice as the establishment of new rights and programs for the oppressed; and peace as the security, harmony and respect of all (Hauss, 2010; Lederach, 1997). 


\section{Belisario Betancur (1982-1986) and the Search for a Democratic Peace}

At the end of the 1970s, Colombia was experiencing popular strikes, the murder of political leaders, and an increase in kidnappings in urban areas. The government's response to this violent social phenomenon was the creation of The Security Statute. It allowed the military criminal justice board to judge a series of crimes committed by civilians against other civilians and the military through Oral Councils (Wills Obregón, 2015, p. 27). The armed forces noted that this security statute created the opportunity to fight the "internal enemy" that threatened "national interests." However, the analyst Catalina Jiménez (2009, p.80) contended that this led the military to "consider that any opposition or critic to the state was a threat to the transcendental political values" of the nation. The Security Statute led to Human Rights violations such as torture and detention. Due to this authoritative regime that expanded the military power, people from different political ideologies - liberals, conservatives, socialists, and communists - created the Permanent Committee of Human Rights Defense in 1979, which tried to denounce the violations emanating from the government and military (Wills Obregón, 2015, p. 29). However, these kinds of initiatives did not have force enough to be a counterweight the authoritative military behaviour of the state. This is a political period where the Colombian Government pursued peace via Realism. The focus of this peace endeavour was the protection of national security via militarization and the defeat of the guerrilla groups.

Belisario Betancur was elected President of Colombia in August 1982. He delivered a speech that addressed the years of authoritarianism under the Security Statute of Julio César Turbay. Throughout the presidential campaign, he proposed a new understanding of the conflict. He spoke of injustice and inequality, the context that contributed to the rise of the armed rebellion, and he recognized the guerrillas' political status. In so doing, he propose a dialogue with the guerrillas (Wills Obregón, 2015, p. 30). Once he assumed the presidency, the government began a peace process with FARC-EP, which culminated in The Uribe Agreements, and the ceasefire signed on May 28, 1984, in which the parties committed to a long-term ceasefire and the joint search for a political solution to the Colombian armed conflict.

In Betancur's administration, two elements were introduced to the national political discourse. On the one hand, it was recognized that the armed opposition was a political actor and that it was necessary to open up a dialogue with them. On the other hand, it was stated that Colombia, like other countries in Latin America at this time, required a process of democratic openness. The new approach was a radical turnaround from the previous government. For the new government, the fundamental step in strengthening democracy in Colombia was the negotiation with the guerrillas on the basis of their eventual participation in a reformed political system (Chernick, 1996). This led to a dialogue with various armed groups and included social reforms associated with the peace process related to recovering areas that had been affected by violence and improving the standard of living of the poor through a housing plan without having a down payment on homes. Under these circumstances, the presidential pacifying discourse had great national support (Afanador, 1993 as cited in Padilla, 2017, p. 88). Therefore, the government focused on the search for peace with the various guerrilla groups, reconstituting the Peace Commission created by the predecessor government. The Peace Commission was made up of forty representatives from the different social sectors and had the following main aims: 1) incorporation of the different armed groups into civil social life; 2) recovery and development of regions requiring the presence of the state's institutions; 3) substantial enhancement of justice, citizen security, surveillance public administration, and the protection of citizens' rights; 4) the efficiency of state institutions and public expenditure (Gómez Araujo, 2002). The goal of the new government was to minimize the conflict with the guerrilla groups, to improve the democratic institutions and to integrate Colombia into the regional market and policies. The turning point of Betancur's administration was to provide a political status to the guerrilla groups, as well as rationalizing the state institutions and public spending. This element opened the door to the possibility of negotiating a win-win solution instead of pursuing peace via militarization and to strengthen the democracy. 
In addition, in 1982 the Congress of the Republic, at the initiative of the Government enacted the Act 35, known as the Amnesty Act. This act established the peace process schedule and included amnesty; political, economic, and social reforms; and the disarmament of the guerrilla groups. However, one of the difficult areas of the peace process was the amnesty given to the perpetrators and accomplices of political offence acts committed before the issue of the Amnesty Act. Some scholars argue that this act was ambiguous and dangerous because there was not any certainty that it could help to overcome the conflict and in fact, increased it (Padilla, 2017). It did not request the guerrilla movements the abandonment of weapons, but it increased the penalties for those who had illegal possession of weapons, and it did not set territory as a buffer zone for the guerrillas (Afanador, 1993 as cited in Padilla, 2017, p. 90). In other words, this process lacked any sense of justice or truth.

As a consequence of this process, in November 1985, the political movement called the Patriotic Union (UP) emerged. The UP was a political party that included FARC-EP members, members of political parties, civil society, and trade unionists. This movement participated in the regional and local elections becoming a political alternative to the bipartisanship made up by Conservatives and Liberals. Shortly thereafter, M-19 and EPL were added to this agreement (Wills Obregón, 2015, p. 30). However, the opponents and government opposition argued that the peace agreement was nonsense, having taken into account the increase in kidnappings and extortions carried out by the guerrillas; and therefore, even in the middle of the many dialogues with the guerrillas, these opposition groups had increased their strength (Wills Obregón, 2015, p. 30).

In conclusion, the peace process initiated by Betancur's administration has the characteristics of democratic-liberal peace. In this peace process, the government included components related to the improvement of democratic institutions, citizen security, public surveillance administration, and the protection of citizen's rights. However, it did not include disarmament and the ambiguity of the Amnesty Act maintained the idea of injustice. In spite of the new political status of the guerrilla groups, the process did not challenge the roots of the conflict. Meanwhile, some guerrilla groups participated in democratic elections. Regardless of the fact that this peace process was not completely successful, this new approach was important as it changed the peace-seeking paradigm that opened the door to negotiated peace with different groups.

\section{Virgilio Barco (1986-1990). A Continuation of Democratic-Liberal Peace}

When Virgilio Barco (1986-1990) came to power, his government made an evaluation of Betancur's peace policy. The new President's advisors concluded that their predecessors did not have a defined project, there were no clear goals or precise timelines or deadlines, and there were too many social actors involved without a defined and effective commitment from the government (Chernick, 1996). Instead of a broad and open negotiating agenda, the new government wanted to negotiate with guerrillas only on the stages of disarmament and their subsequent incorporation into legal political life. This government believed that other political and social issues should be addressed with other opponents who did not belong to the guerrilla movements (Chernick, 1996).

Virgilio Barco developed a series of programmes aimed at the rehabilitation of regions affected by violence such as the National Rehabilitation Plan and the Establishment of Municipal and Departmental Rehabilitation Councils, which should encourage citizen participation (Chernick, 1996). Despite these efforts to focus on social issues related to the conflict; in the end, the main governmental objective was not to negotiate a solution to the armed conflict, but to legitimize the state and delegitimize the guerrilla groups. In other words, there was no longer a negotiation between two parties with the same status, but between a state that consciously represented the citizenship and guerrilla groups that were less legitimate. Nevertheless, the guerrillas could aspire to participate in the political life of the country. The strategy was summarized in the 
motto "hand tenderness; firm pulse" which is the same as the diplomacy of "sticks and carrots." The strategy worked partially well. It achieved the incorporation of some guerrilla groups such as M-19, many members from the EPL, and the Quintín Lame Indigenous group. It was a partial-liminal peace that did not address the conflict's causes such as the land problem and it did not take care of the victims. The first three years of this strategy served to pressure some groups into negotiations.

In conclusion, despite the different treatment given by the government to the guerrilla groups, the same peace framework used by the previous government was implemented. Democratic-liberal peace was the guide to address the conflict, specifically using the diplomacy of stick and carrot and incorporating some armed group members into the civil society to participate in democratic elections. In the end, the state did not address the roots of the conflict but, instead, tried to enhance the democratic institutions.

\section{Andres Pastrana (1998-2002)}

The effort made during Andrés Pastrana's administration was preceded by several events, which undoubtedly created notions in the public opinion, a positive attitude towards the eventuality of having political negotiation. In 1992, during the presidency of César Gaviria there were attempts to negotiate with the Coordinadora Guerrillera Simón Bolivar (CGSB), an umbrella organization that gathered the different guerrilla groups together. However, there was also a declared open war against the rebel groups since the discussion about the ceasefires and ending the hostilities was not successful. During Ernesto Samper's administration between 1994 and 1998, it was not possible to initiate dialogues because no agreement was reached regarding the demilitarization of certain municipalities which had been requested by the guerilla groups. During the same period, the Armed Forces suffered harsh defeats in municipalities such as Puerres, Las Delicias, El Billar, Miraflores, and Patascoy, among others. Therefore, peace was on the agenda during the race for the presidency in 1998. The meeting between the presidential candidate Andrés Pastrana and FARC-EP members was an important element in helping him to win the elections.

In this process, there was a struggle to balance forces. The correlation of forces is a term that goes beyond the military and is, therefore, closely related to politicians' motivations from which it is possible to approach negotiation (Leguizamo, 2002). The dialogues started in January 1999. FARC-EP and the Colombian government declared the goal of achieving a 'Common Agenda for Change towards a New Colombia in Peace' that was embodied in twelve themes. Topics such as economic, political and agrarian reforms; illicit crops; Human Rights; international humanitarian law; natural resources; state, justice and political reforms; and armed forces and international relations were central in the negotiation (Ríos, 2015). At no point in the negotiation process did issues relevant to the peace process, such as the discussion of disarmament, appear.

Scholars argue that for neither of the two actors, from a rational perspective, there were any real motivations to a have real negotiation or for bringing to an end the dynamics of armed conflict. Andrés Pastrana's administration conceived that the growing strength of the institutional and security dimension of the Colombian state was necessary and possible. Under this framework, the new relationship with the United States emerged, and the investment into strengthening and modernizing the military forces helped the government to conceive a near horizon in which the Colombian State could assume an advantageous position in the negotiation, given the unequal and beneficial correlation of forces (Ríos, 2015).

The army's modernization initiative and profound transformation from the government is only understood on the basis of the implementation of Plan Colombia. Plan Colombia was an important initiative of the government's plan, which was welcomed by U.S. President Bill Clinton in 1998 when he promised to allocate more military aid to Colombia in order to combat drug trafficking and to strengthen democracy (Fajardo, 2003 as cited in Ríos, 2015). Initially, the Plan Colombia had an orientation toward social investment to achieve political and social stability in the region. However, Colombia, especially since the subsequent arrival 
of George W. Bush to the USA presidency, happened to erect itself as a program through which the majority of its resources were designated to the fight against narcotics. This process had a special emphasis on aerial fumigation instead of manual eradication of cocaine crops. The manual eradication of cocaine crops was one of the nonnegotiable points proposed by FARC-EP (Ríos, 2015).

In this negotiation, peace was conceived as an equation that combined the strengthening of democracy and economic development without looking at the victims and the conflict's roots. It meant that a long-term process was overlooked including positive peace. Plan Colombia was implemented on the basis of six central objectives: 1) to strengthen the fight against drug trafficking, and to integrate the action of the armed forces; 2) to strengthen the judicial system and the fight against corruption; 3) to neutralize the financial system of the drug trade in order to revert it in favour of the state; 4) to neutralize and combat the agents of violence that act in connivance with drug trafficking; 5) to integrate the initiatives produced at different local-nationalinternational geographic extent, and finally 6) to strengthen and expand plans for alternative development in areas affected by drug trafficking (Ríos, 2015).

Between 1998 and 2002, there were 17,818 violations of international humanitarian law; 17,043 violations of Human Rights; political and social violence generating 18,595 victims; and 14,342 deaths due to the violence (Otero, 2007 as cited in Ríos, 2015). The number of displaced persons reached the highest levels in the Colombian history that, in sum with all the government's previous efforts to defeat the guerrillas, blurred the whole peace process and negotiation by Andrés Pastrana, creating the circumstances for the arrival of Álvaro Uribe to the Colombian presidency (Ríos, 2015).

In conclusion, Andres Pastrana's peace negotiation was a mixture of realism and democracy liberal peace. While both FARC-EP and the Colombian Government used the negotiations to strengthen their military forces. The government attempted to develop democratic institutions. FARC-EP gained political status and was accepted as a party to negotiate economic and political issues. However, neither of the parties trusted each other. The intervention of a third party was used to strengthen the government's military actions while FACR-EP reached its highest number of members in their history.

\section{Juan Manuel Santos (2010-2018): A Mixture of Democratic Liberal Peace and Peace and Conflict Resolution}

This context led to Alvaro Uribe Velez's presidency and his politics of "Democratic Security" that was an extension of Plan Colombia and was characterized by an offensive military response against FARC-EP with the support of the US. In Uribe's administration, the relationship between the Colombian Government and FARC-EP was characterised by many events, such as: 1 ) the release of dozens of imprisoned FARC-EP rebels by the government in the hope that the FARC-EP would reciprocate by releasing hostages. 2) The Venezuelan president, Hugo Chavez, agrees to invite the rebels to talks on a prisoner exchange agreement. As a result, the FARC-EP released later two "high profile hostages", Clara Rojas and Consuelo Gonzalez. 3) An attack done by the Colombian Army in Ecuador killed FARC's number two, Raul Reyes, and triggered a diplomatic crisis between Colombia and Ecuador. 4) The FARC-EP announced the death of its leader and founder, Manuel Marulanda, from natural causes. And 5) the Colombian Army "rescued" 15 hostages, among them Ingrid Betancourt, the former presidential candidate, who was held captive for six years.

After Uribe's administration, FARC-EP decided to negotiate peace in 2012, with the Government of President Juan Manuel Santos. This peace process was supported by the international community including Norway, Cuba, Venezuela, and Chile, who helped to establish key points in the negotiation process such as the abandonment of weapons, reparations and the recognition of victims, the reincorporation of former guerrillas into civilian life, and a transitional justice system to judge all those who participated in the conflict. 
Added to this international support, the participation of civil society in the 2016 peace agreement was central to its success. Several groups of victims and social organizations were invited to contribute in the Havana dialogues (Cuba). However, there were some groups that did not have the opportunity to participate in the peace agreement process as compared to other groups. For example, the negotiators invited six victim delegations whose voices were added to the peace agreement process. Yet ethnic and cultural groups were not invited nor included in the peace agreement process until the very last moment.

The new President and the FARC-EP started a new negotiated peace agreement which contained six major items: 1) Comprehensive rural reform seeking to establish the foundation for the transformation of rural areas, thus creating the conditions to ensure the health and well-being of the rural population. 2) Political participation seeking to promote and strengthen citizen participation in matters of public interest outlawing violence as a method of political action. 3) Ending the conflict illustrated within the agreement as a bilateral and reaching a definitive ceasefire and the cessation of hostilities, and putting arms beyond further use. 4) Solving to the problem of illicit drug states. That both parties must commit to finding a solution to the problem of illicit drugs, and clarifying the historical relationship between the armed conflict and the cultivation, production and commercialisation of illicit drugs, and the laundering of assets derived from this phenomenon. 5) A comprehensive system for truth, justice, reparations and non-repetition aims to contribute toward the historical clarification of what happened in the conflict, and to promote and contribute to the recognition of the victims, while recognizing the responsibility of those that were involved directly or indirectly in the armed conflict; and promoting coexistence across the country. 6) The implementation and verification of mechanisms seeking to monitor and verify all of the party's compliance with their commitments (Presidencia de la República de Colombia, 2016).

New elements were added to this peace process. In this case, victims were central actors in the negotiation; the international community played a "neutral role" and was important in building trust between the parties; the roots of the conflict, such as the land problem, were significant topics in the negotiation; and justice, truth, and mercy were incorporated into a new system of justice that would assess the level of responsibility of the different actors involved in the conflict. In addition, the High Commissioner for Peace, Sergio Jaramillo, proposed the perspective of Territorial Peace to include the population in the peace process, and its articulation to the agreement implementation. From this perspective, the High Commissioner for Peace pointed out that "there is no possibility that Colombia will progress in an equitable and sustained manner if we do not solve the problem of the rural areas and clarify and guarantee land property rights" (Jaramillo, 2014). Therefore, the Commissioner planned a participatory process "from the bottom up" in the territories (Jaramillo, 2014). However, the concept of Territorial Peace leads to an academic and political debate since there is no complete or developed vision of its meaning. Some scholars argue this concept is another element used by democratic-liberal defenders to implement neo-liberal economic perspectives (Bautista, 2017), while others emphasise that Territorial Peace is central to transform the social realities in the communities (Martinez, 2019) and to develop the community capacities to build peace (Aunta \& Barrera, 2016).

The agreement's title - A General Agreement for the Termination of the Conflict and the Construction of a Stable and Lasting Peace - also suggests the type of framework which was conceived for the implementation. The title can be divided in two parts; 1) the termination of the conflict includes FARC-EP to lay down arms as well as the reintegration and reincorporation process of former rebels; and 2) the construction of a stable and lasting peace, indicating the present and future of the process, including structural, social, cultural, economic, political, and individual transformation, and not only the termination of the conflict.

This peace process aims to transform the Colombian conflict. The leadership from both parties, the consideration towards building peace in the medium to long term, the win-win perspective, the acknowledgment of FARC-EP as a political actor, the participation of victims, and the search to tackle the injustices that escalated the conflict were all significant. To some degree, the process looks to re-establish 
trusting relationships that were broken, such as the meeting between victims and victimizers, and the incorporation of many members of the former guerrillas into the civil society.

However, the latest Colombian peace agreement also is criticized for focusing on (re)constructing the Colombian State to privilege capitalism. Sergio de Zubiria (Kbeza Rodante, 2016) underlines that there are different approaches from diverse political groups to for the peacebuilding in Colombia. On the one hand, there is a perspective to recover the "order" via the establishment, which includes Juan Manuel Santos's administration privileging capitalism and the political right wing represented by the political party Centro Democrático that claims "revenge". On the other hand, he also argues that the political left-wing party's discourses gather around four visions. Firstly, some argue that the termination of the conflict only concerns the person who was the agent of its unleashing; secondly, another trend defends that while capitalism will continue to exist, peace will still be a fiction; the third vision considers that the agreements have too many limits, in particular related to the jurisdiction of the peace; and finally, there is another vision stating that the end of the conflict can open a window for a new correlation of popular forces towards a process that takes on reforms in the short and medium term (Kbeza Rodante, 2016).

In addition, despite the fact that the land and the drug trafficking are two of the main areas addressed in the 2016 agreement, it seems that there was a lack of new elements aiming to change the structure of those problems. The agrarian agreement raises doubts about the regulations in force in the peasant reserve zones and, in the areas, where local action plans are applied, as well as about the faculties of the communities and the bodies created to make binding decisions. In general, it seems that the application of the various plans will depend on general legal rules. Although consultation with communities is mentioned in many cases; it does not seem to be implemented consistently, for example, mining projects in indigenous areas (Melo, 2016). On the other hand, the illicit drug agreement seems to echo current policies. For example, it includes the commitment to treat drug consumption as a health problem, which in general terms is already accepted in the country. Furthermore, it comprises the voluntary eradication of illicit crops, although if this is not achieved or communities oppose to it, there may be manual eradication by the government. Peasants will not be criminally punished, which is in fact already happening (Melo, 2016).

These elements allow us considering that in this peace process there was an attempt to build a hybrid process, incorporating elements from CR framework with features from democratic-liberal peace perspective. Despite the fact that there has been participation of civil society movements, many of them claim a lack of representation or that their voices have not been sufficiently taken into account, in order to satisfy their local needs and to support social dynamics.

\section{Conclusions}

In conclusion, it is important to explore in more detail the components and the contexts in which these peace processes were developed in order to understand more accurately the elements in each perspective that worked or failed in finding a peaceful, fair negotiation in the Colombian conflict. This article also raises questions for future research about the peace agreement implementation; for example, if the hybrid framework of the peace agreement process is being correctly translated into the implementation, or whether the communities and people in Colombia are perceiving a conflict transformation thanks to the peace agreement.

An analysis of the three different peace processes carried out in Colombia helps us to understand the strengths and weaknesses of building the peace in this country. Previous to 1982, the framework used to achieve peace was Realism. When Belisario Betancur took over Colombia's presidency, it was a turning point within the peace framework from Realism to Democratic and Liberal Peace that, with some differences, was also developed by the Andres Pastrana's administration. Pastrana tried to accomplish peace with a mixture of Realism and Democratic-Liberal Peace that led to a deescalation of the violent conflict in Colombia. It seems 
that it was not until 2012, in Juan Manuel Santos' administration, that Conflict Resolution was implemented as a central framework to achieve the peace. However, the latest peace agreement between the Colombian Government and the FARC-EP also keeps basic elements from the Democratic-Liberal Peace approach, essentially those aiming to strengthen the state and its institutions over local communities. In this sense, the success of the agreement is given by the end of the FARC-EP as an armed organization and its transformation into a political party that submits to the legal norms and benefits from some special treatment, which can be understood as a win-win arrangement without changing structural problems, neither positive peace.

\section{References}

Aunta, A., \& Barrera, V. (2016). Conflictividades y agendas territoriales. Red Prodepaz; Clacso. http://biblioteca.clacs o.edu.ar/Colombia/cinep/20160929111556/Conflictividades_y_agendas_territoriales.pdf

Bautista, S. (2017). Contribuciones a la fundamentación conceptual de paz territorial. Revista Ciudad Paz-ando, 10(1), 100-110. https://doi.org/10.14483/2422278X.11639

Beriker, N. (2009). Conflict resolution: the missing link between liberal international relations theory and realistic practice. In D. Sandole, S. Byrne, I. Sandole-Staroste, \& J. Senehi (Eds.), Handbook of conflict analysis and resolution (pp. 256-271). Routledge.

Chernick, M. W. (1996). Introducción. Aprender del pasado: breve historia de los procesos de paz en Colombia (1982-1996). Colombia Internacional, 36, 4-8. https://doi.org/10.7440/colombiaint36.1996.02

Galtung, J. (1975). Three approaches to peace: Peacekeeping, peacemaking, and peacebuilding. In J. Galtung (Eds.), Peace, war, and defense: Essays in peace research (pp. 282-304). Christian Ejlers.

Gómez Araujo, L. A. (2002). Reflexiones acerca de los procesos de paz en Colombia. El marco jurídico y otras consideraciones. Revista de Derecho, 18, 118-134. http://rcientificas.uninorte.edu.co/index.php/derecho/artic le/viewArticle/2978

Gutiérrez Loaiza, A. (2012). Negociaciones de paz en Colombia, 1982-2009. Un estado del arte. Estudios Políticos, 40. https://revistas.udea.edu.co/index.php/estudiospoliticos/article/view/13210

Hauss, C. (2010). International Conflict Resolution. Continuum.

Jaramillo, S. (2014, March 13). La paz territorial. In Todo lo que debería saber sobre el Proceso de Paz. Konrad Adenauer Stiftung. https://www.kas.de/c/document_library/get_file?uuid=dc51de20-3b9c-af6c-470e-89dd3bffe186\&g roupId $=271408$

Jiménez, C. (2009). El Estatuto de Seguridad, la aplicabilidad de la doctrina de la Seguridad Nacional en Colombia. Colección, 20, 75-105. https://dialnet.unirioja.es/servlet/articulo?codigo $=3226580$

Lederach, J. P. (1997). Building peace: sustainable reconciliation in divided societies. United States Institute of Peace Press.

Leguizamo, C. (2002). Reflexiones sobre el Proceso de Paz del Gobierno de Andrés Pastrana y las FARC-EP (1998-2002).Archivos de Economía, 204. https://colaboracion.dnp.gov.co/CDT/Estudios\%20Econmicos/204 .pdf

Mac Ginty, R. (2006). No War, No Peace: The Rejuvenation of Stalled Peace Processes and Peace Accords. Palgrave Macmillan

Martínez, H. (2019, March 20). Insistamos en la paz territorial [Blog post]. Dejusticia. https://www.dejusticia.org/c olumn/insistamos-en-la-paz-territorial/

Melo, J. O. (2016). Resumen del acuerdo de paz. Revista de Economía Institucional, 18(35), 319-337. http://doi.org /10.18601/01245996.v18n35.19

Padilla, M. J. (2017). Los embates por la paz: historia de los diálogos de paz durante el gobierno de Belisario Betancur con los grupos guerrilleros, Colombia. Revista Forum, 10(11), 85-104. https://revistas.unal.edu.co/index.php/ forum/article/view/69059 
Pearson, F. S., \& Lounsbery, M. O. (2009). The challenge of operationalizing key concepts in conflict resolution theory in international and subnational conflicts. In D. Sandole, S. Byrne, I. Sandole-Staroste, \& J. Senehi (Eds.), Handbook of conflict analysis and resolution (pp. 71-84). Routledge.

Presidencia de la República de Colombia. (2016). Colombia's agreement to End Conflict and Build Peace. Alto Comisionado para la Paz. http://www.altocomisionadoparalapaz.gov.co/herramientas/Documents/summaryof-colombias-peace-agreement.pdf

Ríos, J. (2015). Del Caguán a la Habana. Los diálogos de paz con las FARC en Colombia: una cuestión de correlación de fuerzas. Revistas de Estudios en Seguridad Internacional, 1(1), 63-83. http://doi.org/10.18847/1.1.4

Ryan, S. (2009). Conflict transformation: reasons to be modest. In D. Sandole, S. Byrne, I. Sandole-Staroste, \& J. Senehi (Eds.), Handbook of conflict analysis and resolution (pp. 303-314). Routledge.

Valencia Agudelo, G. D. (2017). Presentación sección temática. Un balance de los estudios sobre la paz negociada en Colombia. Estudios Politicos, 50. http://doi.org/10.17533/udea.espo.n50a11

Valencia, G. (2016). Violencia, conflicto armado y procesos de paz en las dinámicas indagativas de las ciencias sociales y humanas en Colombia. Debates, 74, 79-86. https://dialnet.unirioja.es/servlet/articulo?codigo $=6131797$

Wani, H. A., Suwitra, A., \& Fayeye, J. (2013). Conflict Resolution and Conflict Transformation: Some Reflections. Jurnal Kajian Pendidikan, 3(1), 35-44. http://journals.mindamas.com/index.php/atikan/article/view/143

Wills Obregón, M. E. (2015). Los tres nudos de la guerra colombiana: un campesinado sin representación política, una polarización social en el marco de una institucionalidad fracturada, y unas articulaciones perversas entre regiones y centro. Comisión Histórica del Conflicto y sus Víctimas.

Kbeza Rodante. (2016, March 12). Sergio de Zubiría: La Paz territorial [Video File]. YouTube. https://www.youtub e.com/watch?v=l1xQ_pi8bkE

\section{Notes}

* $\quad$ Artículo de investigación científica

\section{Licencia Creative Commons CC BY 4.0}

Cómo citar este artículo: Luna Eslava, L. R. (2020). Tres procesos de paz en Colombia: un breve análisis desde tres perspectivas de los estudios de paz y conflicto. Papel Político, 25. https://www.doi.org/10.11144/Jave riana.papo25.tcpp 